Justifying

International

Acts 

Justifying

International

Acts

LEA BRILMAYER

Cornell University Press

Ithaca and London 
Copyright (C) 1989 by Cornell University

All rights reserved. Except for brief quotations in a review, this book, or parts thereof, must not be reproduced in any form without permission in writing from the publisher. For information, address

Cornell University Press, 124 Roberts Place, Ithaca, New York I4850.

First published 1989 by Cornell University Press.

International Standard Book Number 0-801 4-2278-7

Library of Congress Catalog Card Number 89-7 I 2 I

Librarians: Library of Congress cataloging information appears on the last page of the book.

The paper in this book is acid-free and meets the guidelines for permanence and durability of the Committee on Production Guidelines for Book Longevity of the Council on Library Resources. 


\section{To W.C.H.}


